\title{
A KORAI NYELVTANÍTÁS TÖRTÉNETE NYÍREGYHÁZÁN A RENDSZERVÁLTÁSTÓL NAPJAINKIG
}

\section{Szerzők:}

Dr. Nemes Magdolna, Debreceni Egyetem Gyermeknevelési és Gyógypedagógiai Kar

Nagy Anikó

Debreceni Egyetem

ancsa147@gmail.com

\section{Lektorok:}

Első szerző e-mail címe:

nemesm@ped.unideb.hu

Nemes Magdolna és Nagy Anikó (2018): A korai nyelvtanítás története Nyíregyházán a rendszerváltástól napjainkig. Különleges Bánásmód, IV. évf. 2018/1. szám, 7-18. DOI 10.18458/KB.2018.1.7

\begin{abstract}
Absztrakt
Tanulmányunkban a kisgyermekkori nyelvtanulás jelenségével foglalkozunk. A szakirodalom áttekintése során bemutatjuk, milyen szerepe van az életkornak az idegennyelvtanulásban, melyek az alapvetö különbségek a nyelvelsajátitás és a nyelvtanulás között. A továbbiakban ismertetjük, milyen intézményes lehetöségek (üzleti vállalkozásként müködö nyelviskolák, családi bölcsődék) vannak a kisgyermekkori nyelvtanulásra Nyíregyházán 2017ben. A kutatásunk kerestük a választ arra is, milyen módszertani szempontból változások figyelhetök meg a rendszerváltás idején zajló és a jelenlegi nyelvi foglalkozások között. Kutatási módszerként az interjút választottuk, mert így képet kaptunk az 1990-es években zajló foglalkozásokról és a kezdeti lépésekröl is. 2017 tavaszán nyolc interjút készítettünk, a megkérdezettek között voltak óvodapedagógusok és nyelvtanárok, aki óvodai angol tevékenységeket vezettek. Az adatközlök elmondása alapján megállapithatjuk, hogy 2017-ben a Nyíregyházán müködö 34 óvodából 23-ban van korai angol nyelvi fejlesztés (68\%), emellett jelen van az óvodákban a német és a francia nyelv is. Megállapitottuk továbbá, hogy az 1990es évektöl folyamatosan nö azoknak az óvodáknak a száma, ahol heti rendszerességgel szerveznek játékos idegen nyelvü foglalkozásokat. Az interjúalanyok visszaemlékezéseiböl az is kiderült, hogy a rendszerváltás idején nehézséget jelentett az idegen nyelvi foglalkozások szervezésénél a személyi feltételek biztositása. Napjainkban több óvodában van olyan, nyelvtudással rendelkezö óvodapedagógus, aki vállalja, hogy az óvodás gyerekek nyelvi fejlesztésében részt vesz. A játékosság, az audiovizuális eszközök és a szemléltetőeszközök a kezdetektöl fogva kiemelt fontosságúak az óvodákban, és a pedagógusok igyekeznek minél változatosabb módszerekkel biztositani a 4-7 korú gyerekek idegen nyelvi fejlesztését.
\end{abstract}

Kulcsszavak: korai idegennyelv-tanulás, Nyíregyháza, játékosság, módszertan 
Diszciplina: pedagógia

\begin{abstract}
In our paper we deal with the significance of learning languages at an early age. While going through the literature of the topic, we draw attention to the importance of age in learning a language, as well as the basic differences between language learning and language acquisition. In the following, we present the options outside the family (such as language schools and family creche 'családi bölcsöde') for learning a language at an early age in Nyiregyháza in 2017. In our research, we also wanted to find out what differences can be seen in terms of methodology of early foreign language activities in kindergartens/preschools between the activities held during the change of the political regime in Hungary (1989/1990) and today. We chose the interview as a research method, because in this way we can get a picture of the foreign language activities in kindergartens/preschools and their first steps in the 1990s when they were first available to children. We made eight interviews in spring 2017, asking kindergarten pedagogues/early childhood educators and language teachers as well who had held English activities in kindergartens/preschools. Based on the information we received from the informants, we can say that early English activities were available in 23 kindergartens/preschools out of the 34 kindergartens/preschools (68\%) operating in Nyiregyháza, Hungary in 2017. In some kindergartens/preschools children can also take part in early French and German activities. We have also realized that the number of those kindergartens/preschools which organize playful foreign language activities on a weekly basis has been increasing since the 1990s. From the recollections of the informants, it has also been revealed to us that during the change of the political system providing personal criteria (that is finding qualified teachers) was the most difficult task. Nowadays, several kindergartens/preschools employ kindergarten pedagogues who are able to take part in the language development of children in a foreign language as they are competent users of it. Playfulness, using audiovisual devices and a lot of props has been highly important since the very beginning in the kindergartens, and pedagogues have also been doing their best to use and try different methods in order to develop the foreign language competence of children aged 4-7.
\end{abstract}

Keywords: language learning at an early age, Nyíregyháza, playfulness, methodology

Disciplines: pedagogy

\title{
Bevezetés
}

Az Európai Uniós csatlakozás óta (2004) Magyarországon is fontos szerepet kap a nyelvtanulás. Manapság egyre több az átmenetileg külföldön élö család és egyre gyakoribbak a vegyes házasságok is. „Multikulturális világunkban mára a mindennapi élet is számtalan olyan helyzetet teremt, amelyben nyelvtudás nélkül nem, vagy csak alig lehet boldogulni, ezért az idegen nyelvek ismeretének ma igen magas a társadalmi értéke, hiszen a hasznossága egyértelmü" (Téglás 2017).

Nem csak ahhoz szükséges a nyelv, hogy utazzunk, vagy külföldi egyetemen tanulhassunk, hanem az országon belüli munkavállalásnál is előnyt élvez, aki magas szintü nyelvtudással rendelkezik. A multinacionális cégeknél alapkövetelmény a nyelvismeret, de már egyetemi 
diplomát sem szerezhetnek a hallgatók a nyelvvizsga megszerzése nélkül. A nyelvtanulás elősegíti a gyerekek esélyegyenlőségét, mobilitását és az előre nem látható jövő esetén is kapaszkodót jelenthet.

A 21. század második évtizedében is megfigyelhető, hogy a magyar szülök jelentős része törekszik arra, hogy gyermeke minél korábban idegen nyelvet tanuljon. Az elmúlt időszakban megjelentek olyan óvodák és bölcsődék, ahol már egészen fiatal korban elkezdik az idegen nyelv(ek) oktatását. A kisgyermekkori nyelvelsajátítás különbözik a tudatos, hagyományos értelemben vett nyelvtanulástól. A gyerekek életkori sajátosságaira épített tevékenységekkel, mondókákkal, énekléssel és mozgással szinte észrevétlenül tanulnak a gyerekek. Az anyanyelv elsajátításához hasonló folyamatok során az idegen nyelv szavai mellett bizonyos mértékig a nyelvtani szabályai is rögzülnek. A nyelvelsajátítás során nem a korrekció a fontos, hanem a sok ismétlés és a gyakorlás. Nem az a lényeg, hogy a gyermek hibátlanul használja a nyelvet, hanem az, hogy meg merjen szólalni. Ezen kívül az idegen nyelvi fejlesztés, az óvoda egyéb tevékenységeihez hasonlóan, hozzájárul a gyermekek általános kognitív képességeinek a fejlődéséhez is. „Mind a pedagógusok, mind a pszichológusok azt a véleményt képviselik, hogy a korai nyelvoktatás elősegíti a gyermek értelmi, érzelmi kiteljesedését" (Márkus és Trentinné 2014, 104).

A korai nyelvtanulás megvalósulhat intézményes keretek között, de számos más lehetőség is kínálkozik a korosztály számára. Magyarországon is müködnek nyelviskola-hálózatok, üzleti vállalkozások, ahol már akár néhány hónapos kortól várják a gyerekeket. A családon belüli nyelvátadásra is egyre többen vállalkoznak, az érdeklödő szülök internetes blogokról, csoportokból tájékozódhatnak a mindennapi örömökről és nehézségekről ${ }^{1}$.

\section{A tanulmány célja}

Tanulmányunkban a korai nyelvtanulás rendszerváltás utáni történetét és jelenlegi lehetőségeit vizsgáljuk Nyíregyházán, különös figyelemmel arra, hogy családon kívül milyen lehetőségek vannak a gyerekek számára. Azért esett a választásunk Nyíregyházára, mert természeti adottságai és földrajzi elhelyezkedése miatt Szabolcs-Szatmár-Bereg megye kulturális és gazdasági központja, az ország hetedik legnagyobb városa (Kasza-BacsaBunovácz 1998). A 120.000 lakosú város oktatását tekintve rendelkezik alapfokú, középfokú és felsőfokú intézményekkel egyaránt, itt található a nagy múlttal rendelkező Nyíregyházi Egyetem, mely több területen képez hallgatókat. A folyamatos beruházásoknak, korszerüsítéseknek köszönhetően Nyíregyháza modern és barátságos város az ország legkeletibb megyéjében. A város kellően nagy ahhoz, hogy több lehetőséget kínáljon a korai nyelvtanulásra, de nem túl nagy ahhoz, hogy egy dolgozat keretein belül ne lehetne kellö részletességgel áttekinteni a föbb jellegzetességeket. Úgy véljük, ha egy várost alaposan feltérképezünk a korai idegennyelv-tanulás szempontjából, abból következtethetünk a többi település helyzetére is. Az általunk bemutatott zárókép a 2017 tavaszi állapotokat tükrözi majd.

Vizsgálatunk két fő cél mentén szerveződik: egyrészt célunk az, hogy megtudjuk, 2017-ben milyen sajátosságokkal bír a nyíregyházi, önkormányzati fenntartású óvodákban van a játékos idegen nyelvi (angol, német, francia) tevékenység. Ehhez a székhelyóvodák vezetőivel vettük fel a kapcsolatot, akik elmondták, az óvodákban és tagóvodákban milyen idegen nyelvi tevékenységeket tartanak.

\footnotetext{
${ }^{1}$ A családon belüli nyelvátadást, a mesterséges kétnyelvűséget nem tárgyaljuk, ehhez lásd Nemes 2016 és Nemes-Révészné Nagy 2017.
} 
A kutatásunk másik célja, hogy feltárja, a rendszerváltás (1990) idején hogyan indultak az első játékos angol nyelvi foglalkozások, miért indultak el a csoportok és hogyan müködtek, illetve a későbbiekben miként fejlődtek tovább. Azért a rendszerváltást választottuk kezdőpontnak, mert ekkortól volt lehetőség idegen nyelvi foglalkozások szervezésére az óvodákban, minden esetben a fenntartó engedélyével.

\section{Nyelviskolák Nyíregyházán 2017-ben}

Először tekintsük át, hogy milyen korai idegennyelv-tanítással foglalkozó nyelviskolákkal találkozhatunk Nyíregyházán.

\section{Helen Doron Early English nyelviskola}

Nyíregyházán is, mint az országban számos helyen, müködik Helen Doron oktatóközpont, ahol 3 hónapos kortól 19 éves korig angol nyelven tanulhatnak a gyerekek. A nyelvtanulás a Helen Doron módszer alapján, azonos elvek mentén történik a világ összes oktatóközpontjában. A módszer 30 éves múltra tekint vissza, és több mint 35 országban müködnek Helen Doron Early English oktatóközpontok. Világszerte közel két-millió gyerek tanul vagy tanult angolul a Helen Doron módszerének köszönhetően. Magyarországon a módszer 2002 óta van jelen. „A Helen Doron English tanfolyamokban kiemelten fontosnak tartjuk, hogy a gyermekek minél több érzékszervükkel szívják magukba az angolt, gyakorolják első szavaikat és minél nagyobb szókészletet halmozzanak fel (1. kép). Ennek záloga a zene, a mozgás, a játék és a pozitív megerősítés.” (http://helendoron.hu/kids)

\section{1. kép: Helen Doron Early English - augmented reality. Nemes Magdolna felvételei}
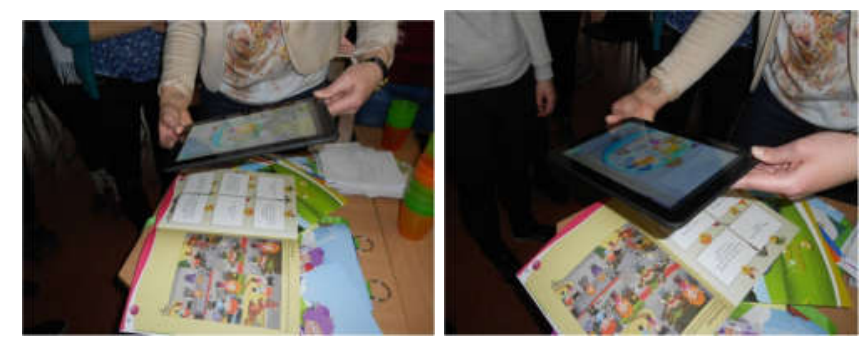

A heti rendszerességgel tartott foglalkozások mellett számos más lehetőséget kínál a HDEE. A nyelviskolában az egyes ünnepekhez kapcsolódó rendezvényeket tartanak, például Halloween, karácsony, farsang vagy a húsvét közös megünneplése. Minden nyáron szerveznek a nyelvi fejlesztés érdekében táborokat, ahol nagyon sok élményhez juthatnak a résztvevő gyerekek. Ezen kívül a nyelviskola diákjai számára elérhető online játszófelület a Kangi Club, ahol oktatóprogramokat használhatnak. Müködik még a Helen Doron rádió, a tankönyvekhez kapcsolódó „,varázslat” (augmented reality - 1.kép) és okostelefon applikáció is (Nemes-Hirzics 2016).

BubblEnglish Angol Gyermek Nyelvstúdió

A BubblEnglish, a Kreatív Angol Gyermek Nyelvstúdió nyelvstúdió Nyíregyházán, a Nád utcában található. A több mint 10 éve müködő vállalkozás kiscsoportos és egyéni foglalkozásokat kínál az 1-14 korú gyerekek számára. A nagy tapasztalattal rendelkező nyelvtanárok az életkorhoz igazított tevékenységekkel, tánccal, dalokkal, versekkel, 
mesékkel, kézműves foglalkozásokkal, és szituációs játékokkal ötvözik a nyelvtanulást. A nyelvtanuláson kívül nagy hangsúlyt kap a kognitív képességek és a kreativitás fejlesztése is. A foglalkozások időtartama 45-60 perc. A bölcsődés és óvodás korosztályon kívül iskolás gyermekekkel is foglalkozik a nyelvstúdió, ötféle csoportban (baba-mama angol, bölcsis angol, ovis angol, kisiskolás angol, nagyiskolás angol) (http://www.bubblenglish.hu/).

\section{Little School Gyereknyelviskola}

A nyelviskola 2017 februárjában nyitotta meg kapuit és 2017 decemberéig müködött. Életkoronként bontott csoportokban várták hetente három alkalommal (hétfö, szerda, péntek) a 4-10 éves korú gyerekeket. Anyanyelvi tanárokkal napi 4 csoporttal müködött az intézmény. Nyíregyházán egyedülállóan csak ebben a nyelviskolában müködött az English School program, aminek érdekessége, hogy minden szombaton 9 órától 13 óráig intenzíven két pedagógus intenzíven, négy blokkban foglalkozott a gyerekekkel (játékos foglalkozás, feladatlapok, angol mesék és végül kreatív foglalkozás) (http://www.littleschoolgyereknyelviskola.hu).

\section{Kicsik Vidám Háza}

Nyíregyházán található a Kicsik Vidám Háza, azaz a KIVIHÁZ angol-magyar családi bölcsőde és gyermekcentrum. Nyíregyházán a KIVIHÁZ volt az első intézmény ahol bevezették a korai idegen nyelvi fejlesztést (2010). A családi bölcsődében két csoportban, két nyelven folyik a gyerekek nevelése. Az angol nyelvü nevelö egész délelőtt a gyerekekkel foglalkozik, a szabad játék ideje alatt is angol nyelven beszél a gyerekekkel. A nyelvelsajátítást elösegítő gazdag anyanyelvi környezetet biztosítja a gyerekek nyelvi fejlődését. Az angol nyelv jelen van az egész nap folyamán, angolul beszélnek tízóraizás, öltözködés, tisztálkodás és az udvari játék közben is. A szakemberek 7 fös csoportokkal dolgoznak, így több lehetőség nyílik az egyéni fejlesztésekre. Az intézményben 2017-ig müködött bölcsődés és óvodás csoport is,ám 2017-től jogszabályi változás miatt erre nincs lehetőség. Az intézményben lehetőség volt délutáni „oviangol” foglalkozásra is, ahol játékos formában tanulhattak angolul a gyerekek, legfeljebb 7 éves korig. A KIVIHÁZ-ban kiemelt helyen van az idegen nyelvi fejlesztés, de nagy hangsúlyt fektetnek a kognitív képességek, a kreativitás és a mozgás fejlesztésére is (http://kivihaz.hu).

\section{Az oral history, mint kutatási módszer}

A rendszerváltás idejétől napjainkig tartó időszak eseményeinek összegyűjtésére az oral history, mint kutatási módszer tünt a legalkalmasabbnak. Amikor a visszaemlékezéseket rögzítjük és elemezzük, a kutatáshoz oral history módszert használunk (Vargáné Nagy 2010). Az oral history módszert elsősorban történészek, szociológusok, néprajzkutatók, használják kutatásaik során, de az oral history számos tudományágban alkalmazható. A kutatási forma segítségével sajátos társadalmi helyzetü csoportokat is vizsgálhatnak. „Céljuk, hogy az oral history módszer alkalmazásával tárjanak fel múltbéli eseményeket, keressenek fel a történelmet tanúsító szemtanúkat, illetve „konzerváljanak” egy-egy számukra fontosnak ítélt hagyományt" (Vargáné Nagy 2010, 33).

„Az oral history szóban elbeszélt történelem. A történelem dokumentálásának olyan módszere, amely a vizsgálandó történelmi korszak élő szemtanúival készített interjúkon alapszik" (Vargáné Nagy 2010, 292). A modern értelemben vett oral history módszer nagyjából a magnetofon elterjedésével azonos idejü, de gyökerei a történelem kezdetéig nyúlnak vissza, hiszen az írásbeliség elterjedéséig az emberi tapasztalatok a szóbeliségen 
keresztül maradtak fent (Vértesi, 2004). Az oral history módszert mindig is használták, például az idősek a szóbeli visszaemlékezéssel adták át a tapasztalatokat a következő generációnak.

Az oral history kapcsán nagy jelentősége van a szóbeliségnek, nem mindegy, hogy ki emlékszik vissza, mert a visszaemlékezők nyelvhasználata, stílusa, hangsúlya eltérő lehet, ugyanakkor sok dologra enged következtetni is. Az interjúalanyok segítségével jobban megértjük a múltban történt eseményeket és az interjúk segítségével olyan információk birtokába juthatunk, melyek semmilyen más forrásból nem lennének biztosíthatóak. A mai digitalizált világban a blogoké, az e-maileké, a különböző elektronikus tartalmaké a vezető szerep, de ügyeljünk arra is (ez az oral history egyik küldetése), hogy a szóbeli történetmondás is maradjon fent, ne vesszen el, mert gyakran pótolhatatlan forrást jelenthet számunkra egyes folyamatok rekonstruálásában és megértésében. „Az oral history a történelem egy kis szeletének megőrzését szolgálja" (Vargáné Nagy, 2010, 296).

Számunkra az oral history azért is fontos forrás témánk szempontjából, mert a rendszerváltás után nem készült az óvodáskori nyelvtanulásról semmilyen írásos anyag Nyíregyházán, tehát a korai nyelvtanulás akkori helyzetéről, történetéröl kizárólag ezzel a módszerrel kaphatunk információt. A oral history módszert alkalmazva óvodapedagógusokkal és nyelvtanárokkal készített interjúk elemzésével igyekeztünk megtudni, hogy a rendszerváltás idején milyen lehetőségek kínálkoztak az óvodáskori nyelvtanulásra. A visszaemlékezéseken keresztül az adatközlők saját emlékeiket idézték fel, múltbéli élményeikről számoltak be.

\section{A kutatás körülményei}

Az interjúk elkészítése során nyolc (részben volt) óvodapedagógussal beszéltünk 2016 ősze és 2017 tavasza között. A beszélgetéseket egy elöre összeállított kérdéssor mentén vettük fel, de nem ragaszkodtunk mereven a leírt kérdésekhez. A beszélgetések során elhangzott nyitott és részben nyitott kérdések által megteremtettük a lehetőséget a saját tapasztalatokra épülő válaszadásra. Az interjú adatközlői egyrészt Nyíregyháza óvodáiban dolgozó óvodapedagógusok és nyelvtanárok voltak, akik megfelelö információkkal rendelkeznek az óvodai nyelvi foglalkozásokkal kapcsolatban. Az adatközlők egy másik csoportja az 1990-es években Nyíregyháza óvodáiban dolgozott és idegen nyelvi foglalkozásokat szervezett. Az interjúalanyokat előzetes ajánlások alapján a „hólabda” módszer segítségével kerestük fel. A helyszínek különbözőek voltak, legtöbbször egy óvodában készült az interjú, a nyugdíjas adatközlőkkel az otthonukban vagy elöre egyeztetett helyszínen beszélgettünk. Tapasztalataink szerint a megkérdezettek szívesen válaszoltak a kérdéseinkre, és próbáltak minél részletesebben felidézni a korábbi eseményeket. Azonban volt olyan adatközlő is, aki szükszavúan, egy-két mondatban válaszolt kérdéseinkre, az ő esetében igyekeztünk direkt és mélyítő kérdésekkel továbbvinni az interjút. (Az adatközlőkröl bővebb információ a mellékletben olvasható.)

\section{Az óvodák számának alakulása a rendszerváltástól napjainkig}

Az adatközlők elmondása alapján a rendszerváltás után 28 önálló óvoda müködött Nyíregyházán. Az önálló óvodákban legalább 2-3 csoport müködött, de gyakori volt a 8-9 csoportos óvoda is. Azokat az intézményeket, melyekben egy csoport müködött, csatolták a nagyobb óvodákhoz, így a 28 önálló óvodához 6 tagintézményt csatoltak. Közel 20 évig ez a rendszer müködött Nyíregyházán. A 2000-es években csökkentették az önállóan működő óvodák számát, és a kisebb óvodákat tagintézményként csatolták a nagyobbakhoz. Ennek eredményeképpen 18 önállóan müködő óvoda jött létre, hozzájuk csatolva 16 tagintézmény. Az intézményrendszer 2011-ben érte el jelenlegi formáját. Az óvodák elnevezése a négy égtáj 
szerint történik. Az Északi, Keleti, Nyugati és Déli székhelyintézményekbe integrálták a tagintézményeket. Nyíregyházán 2017-ben 34 önkormányzati fenntartású óvoda müködik. Az Északi székhelyintézményhez 9 óvoda, a Délihez 12 óvoda, a Nyugatihoz 5 óvoda és a keleti székhelyintézményhez 8 óvoda tartozik.

A felsorolt 34 önkormányzati óvodából 23-ban tartanak idegen nyelvi foglalkozásokat (68\%), azaz az óvodai tevékenységek megszervezésekor az idegen nyelvi fejlesztést beillesztik a hetirendbe. Mind a 23 intézményben jelen van az angol nyelv, de két helyen szerepel a német mint idegen nyelv és egy helyen a francia nyelv is. Muszka Gabriella 2013ban egy másik kelet-magyarországi nagyváros, Debrecen összes óvodájával (46) felvette a kapcsolatot, és azt tapasztalta, hogy 25 óvodában (54\%) folyik angolnyelv-tanulás (Muszka, 2013, 12.).

\section{Kisgyermekkori nyelvtanulás a 90-es években nyíregyházán}

Az 1990-es években egyre nagyobb teret kaptak a nyugati nyelvek, az angol és a német nyelv szerepe felerősödött. Talán ez volt az első olyan szülöi generáció, amely felismerte az idegennyelv-tudás értékét. A szülők kérésére már 1990-ben volt olyan óvoda Nyíregyházán, ahol szerveztek játékos nyelvi foglalkozásokat. „Azok a szülők is szerették volna, hogy a gyerekük idegen nyelven tanuljon már óvodában, akik jól beszéltek valamilyen nyelvet habár ez elég ritka volt, de leginkább azok vélték fontosnak a nyelvismeretet, akiknek nem volt lehetőségük nyelvet tanulni, de mindenképpen meg szerették volna adni ezt a lehetőséget a gyereküknek" (H.P. 66 Ó) - mondja egy volt óvodavezető.

Az önköltséges foglalkozásokat a napirenden kívül, a délutáni órákban tartották. Az adatközlők elmondása szerint először a német nyelv volt a népszerübb, majd később az angol nyelv váltotta fel: „Nem várt sikere volt a német nyelvi foglalkozásoknak, tömegesen jelentkeztek. A 200 fös óvodában 80-90 gyerek is jelentkezett...... Elöször a német nyelvet tudtuk beilleszteni a kommunikációs képességfejlesztés programunkba, majd évek múltán egy óvodapedagógus angol nyelvvizsgát szerzett és elkezdett angol foglalkozásokat tartani, így párhuzamosan két nyelv is volt az óvodánkban, de néhány hónap alatt a német foglalkozások elnéptelenedtek" (H.P. 66 Ó) - emlékezik vissza a Búzaszem óvoda korábbi vezetője. Az óvodavezető azt is elmondta, hogy a rendszerváltás környékén a szülők a német nyelvet részesítették előnyben, és az óvoda is a német nyelvü foglalkozások vezetésére talált a feladatra vállalkozó pedagógust.

Az idegen nyelvi tevékenységek helyszínéül általában valamelyik csoportszoba szolgált, másutt külön helyiségben várták a gyerekeket. „A mi óvodánkban külön helyiséget tudtunk biztosítani a délutáni tevékenységeknek. Már akkor is volt egy nagy terem, ahol kézmüves foglalkozást, néptáncot és a nyelvi foglalkozásokat tartottuk"- emlékszik vissza az egyik óvoda vezetője (H.P. 66 Ó).

A korai nyelvtanulás során a pedagógiai tényezők között központi szerepe van az idegen nyelvet tanító pedagógusnak. A pedagógus nem csak a saját személyisége révén, hanem mint az oktatási folyamat irányítója, szervezője is részt vesz a folyamatban. A pedagógus választja ki a tananyagot és szervezi meg a különbözö tevékenységeket. A rendszerváltás idején az volt az egyik legsúlyosabb probléma, hogy nem volt szakember, aki az óvodás gyerekek idegen nyelvi fejlesztését végezze. Ez a magyarázata annak, hogy a rendszerváltás után csak megközelítőleg 2-3 óvoda tudta biztosítani a szükséges személyi és tárgyi feltételeit, erre utal az egyik óvodavezető: „Nagyon nehezen lehetett nyelvtanárt találni, még az általános iskolákban is hiány volt nyelvtanárokból. Természetesen orosztanár az volt, de ragaszkodtunk a német vagy az angol nyelvhez. Ismerősök ajánlásával találtunk egy általános iskolai 
némettanárt, aki segített elkezdeni a nyelvi fejlesztést. Később egy föiskolai némettanár is tartott foglalkozásokat, akinek a gyerekei az óvodánkba jártak” (H.P. 66 Ó).

A rendszerváltás után kezdődött a nyelvtanárok átképzése, hiszen a kötelező orosznyelvoktatás megszünésével az orosztanárok állás nélkül maradtak. A nyelvtanárok közül sokan egy újabb nyelvszakot végeztek, így a 90-es évek végére már az angol és némettanárok száma megnőtt. A nyelvtanárok számának növekedésével az iskolai nyelvoktatáshoz könnyebben találtak szakembert, de nyelvtudással rendelkező óvodapedagógus még továbbra is nagyon kevés volt a megyében. Egyre jobban elterjedt az a szokás, hogy az óvodákba általános iskolai nyelvtanárok jártak foglalkozásokat tartani. Ez azonban az óvodapedagógusok véleménye szerint nem volt szerencsés, hiszen az óvodás korosztálynál nem ugyanazokat a módszereket kell alkalmazni az idegen nyelv tanítása során, mint az iskolásoknál: „Angol szakos tanár járt az óvodába angol nyelvre hangolni a gyerekeket, de még nem volt kidolgozott módszertana az óvodás gyerekek életkorához igazított nyelvtanulásnak" (É.G. 59 Ó). Az óvodásokkal foglalkozó nyelvtanárok nehezen tudtak alkalmazkodni a gyerekek életkori sajátosságaihoz, de a tevékenységekben mindig fontos szempont volt a játékosság. Az életkori sajátosságok kapcsán figyelembe kell venni a gyermeki emlékezet sajátosságait, a gyermek koncentrációképességét és motivációját, játék- és mozgásigényét, és még hosszan lehetne folytatni a sort.

Már az 1990-es években is törekedtek arra, hogy játékba ágyazott tanulással valósuljon meg az idegen nyelvi fejlesztés, a pedagógusok felismerték a játékosság, a játékeszközök, játékszerek fontosságát az idegen nyelvi foglalkozásokon. A tevékenységek anyagát a nyelvtanárok választották ki az óvodapedagógusok útmutatásai alapján. A rendszerváltás utáni években és napjainkban is fontos a játékba ágyazott tanulás. Amelyik óvodában volt lehetőség arra, hogy egy óvodapedagógus saját csoportjában nyelvi fejlesztést végezzen, ott igyekeztek a mindennapi kommunikációs helyzetekben is idegen nyelvet használni: „Amikor már volt egy óvodapedagógus, aki beszélt angolul, akkor már a saját csoportjában ő a mindennapos tevékenységekben, angol szavakat, utasításokat használt” (H.P. 66 Ó).

A hatéves gyermek figyelme kétszer-háromszor hosszabb, mint 2-4 éves társaié. Feltehetőleg ez a felismerés állhat a mögött, hogy a minden óvodában 4-5 éves kortól vehettek részt az óvodás gyerekek a foglalkozásokon. Az interjúkból az is kirajzolódott, hogy a 4-7 éves gyerekek hetente 1-2 alkalommal, maximum 15 fös csoportokban vettek részt az idegen nyelvi foglalkozásokon.

A gyermeki emlékezet teljesítőképessége alacsonyabb, mint a felnőtté. A gyermekeknek elegendő időt is kell adni ahhoz, hogy az újonnan hallott nyelvi információkat feldolgozzák. A nyíregyházi óvodákban az idegen nyelvi foglalkozások hossza átlagosan 30 perc volt, a pedagógusok figyelembe vették a gyermekek érdeklődését és életkori sajátosságait. Az is előfordult, hogy a foglalkozások 15-20 percig tartottak, a pedagógusok a saját belátásuk szerint döntöttek a foglalkozások hosszúságáról. A sokféle játékos feladat és tevékenység segíti az idegen nyelv játékos gyakorlását, és az idökeret a gyermekek igényeihez ma is rugalmasan illeszkedik.

Ahogyan több adatközlőnk is elmondta, az óvodákban a 2000-es évek elején elkészítették az idegen nyelvi fejlesztés éves tervezetét. „Régen is és most is a tevékenység anyagát az aktualitások, ünnepek, évszakok, állatok és a gyermekek életkori sajátosságaihoz füződő ismeretanyagok alkották" (É.G. 59 Ó). A tervezetben megjelentek az aktuális nevelési évben tervezett tartalmak, témák, nevelési célok. A Búzaszem Óvodában az angol és német nyelvi fejlesztés megjelent a Helyi Nevelési Programban (2008/2009), a Pedagógiai munkatervben és a nevelömunka értékelésénél is kiemelt helyet kapott. A nevelőmunka értékelése során nyomán követték a gyermekek fejlödését, és azt is, hogyan tudják jobbá tenni a korai nyelvoktatást, milyen módszertani vagy egyéb változtatásokra van szükség. 
Az interjúk elkészítése során úgy tapasztaltuk, az adatközlők legszívesebben az idegen nyelvi foglalkozásokon alkalmazott szemléltetőeszközökről, auditív és audiovizuális eszközökről meséltek. A szemléltető eszközök segítik az asszociációk kialakulását, valamint az új szavak, kifejezések megjegyzését is tovább növeli, ha a gyermek kezébe veheti és/vagy kipróbálhatja az eszközöket. A mimika, a testbeszéd is nagy mértékben erősíti a szóban elhangzott információkat. Már az 1990-es években is az óvoda tárgyi feltételeit kihasználva szervezték a tevékenységeket, az óvodai csoportban található játékokat, társasjátékokat, könyveket, bábokat használtak az idegen nyelvi foglalkozásokon is: „Mivel nem volt internet és nyomtató, így a csoportszobában használt tárgyakat alkalmaztuk, sokszor készítettünk kis kártyákat, amikre rajzoltunk, festettünk, gyakran a gyerekeket is bevontuk a kártyák elkészítésébe" (É.G. 59 Ó). Az auditív eszközök alkalmazására már az 1990-es években is volt lehetőség. A nyelvi foglalkozások elmaradhatatlan eleme volt a magnóhallgatás, melynek segítségével gyorsabban és hatékonyabban tanultak meg a gyerekek egy mondókát vagy egy dalt. A hanganyagokat a nyelvtanárok biztosították, de ahol óvodapedagógus vezette az idegen nyelvi foglalkozásokat, ott az ő feladata volt a hanganyag beszerzése is. Erre így emlékszik vissza az egyik pedagógus: „Nehezen lehetett módszertanilag elfogadott kazettákat szerezni, én a Soproni Óvóképző Intézet nyelvi hanganyagát használtam 1995-96-tól” (É.G. 59 Ó).

A gyerekek motiváláshoz használtak különféle kellékeket, például bábokat is: „Régen is használtunk bábokat minden foglalkozáson. Velem volt Zozo majom, akivel minden humorosabb volt" (É.G. 59 Ó).

A korai idegennyelv-tanulás során a nyelvi fejlődés mellett a célnyelvi ország kultúrájának megismerésére is lehetőség nyílik. Fontos, hogy a gyermekekben a tanult nyelv, az anyanyelvi beszélők és kultúrájuk iránti érdeklődés alakuljon ki. Ez a szempont már a rendszerváltás idején is fontos volt a pedagógusoknak, és igyekeztek a gyerekekkel - játékos formában - az angol nyelvü országok, szokásait, ünnepeit megismertetni. Az angol foglalkozásokon például gyakran bemutatták az emeletes buszt vagy a zászlót.

Amint már említettük, az idegen nyelvi foglalkozások önköltségesek voltak. Minden óvodában biztosítottak lehetőséget arra, hogy a szülők nyomon követhessék gyermekük fejlődését: „Bármikor érdeklődhettek a szülők, bármikor meglátogathatták a foglalkozásokat, de minden nagyobb téma lezárása után tartottunk egy nyílt foglalkozást, ahol a tanult dalokat és mondókákat mutattuk be" (É.G. 59 Ó).

\section{Összegzés}

Tanulmányunk bevezető részében ismertettük, hogy milyen lehetőségek vannak a kisgyermekkori nyelvtanulásra Nyíregyháza városában. Az oral history módszernek köszönhetően az is kiderült, hogy az 1990-es évektől van játékos nyelvi tevékenység Nyíregyháza óvodáiban és folyamatosan nő azoknak az óvodáknak a száma, ahol heti rendszerességgel szerveznek játékos idegen nyelvü foglalkozásokat. A rendelkezésre álló adatok alapján azt látjuk, a Nyíregyházán müködő 34 óvodából jelenleg 23-ban van korai idegen nyelvi fejlesztés (67\%). 1990 óta, visszaesések nélkül folyamatosan nő azoknak az óvodáknak a száma, ahol a korai idegen nyelvi fejlesztés mellett döntenek az óvodapedagógusok.

Az óvodapedagógusokkal és a nyelvtanárokkal készített interjúkból kiderült, hogy milyenek voltak régen a tevékenységek. A rendszerváltás idején (1990-es évek) és a jelenleg zajló idegen nyelvi tevékenységek között számos különbséget fedezhetünk fel. Egyrészt megváltozott a törvényi háttér, a fenntartó engedélyével szervezhetnek idegen nyelvi tevékenységeket az óvodák, és megjelentek az üzleti célú vállalkozások is a korai angolnyelvoktatás területén. Az 1990-es években gyakran nem óvodapedagógusok tartották a 
nyelvtanulási tevékenységeket, még 2017-ben egyre több óvodában módszertanilag is felkészült pedagógusok tartják azokat. A további különbségek a technika fejlődéséből erednek, és a szemléltetőeszközökre, auditív és audiovizuális eszközökre vonatkoznak. A módszertani szempontból vizsgált idegen nyelvi foglalkozások központi kérdése a játékosság, ami régen is jelen volt minden idegen nyelvi tevékenységben. Az is világossá vált számunkra, hogy az 1990-es években kevés óvodapedagógus beszélt idegen nyelvet, ezért több intézményben általános iskolai nyelvtanárok tartották a foglalkozásokat. Az interjúalanyok visszaemlékezéseiből az is kiderült, hogy nehéz volt az idegen nyelvi foglalkozásokhoz a személyi feltételek biztosítása. A 2000-és évektől kezdve több óvodában van nyelvtudással rendelkező óvodapedagógus, aki vállalja, hogy az óvodás gyerekek nyelvi fejlesztésében rész vesz, de még most is vannak olyan intézmények, ahol általános iskolai nyelvtanárt bíznak meg a feladat elvégzésével. A rendelkezésünkre álló adatok alapján megállapíthatjuk, hogy az óvodákban az angol nyelv mellett jelenik meg a német és a francia mint idegen nyelv. Az Eszterlánc Északi Óvodában a Nyíregyházi Egyetem Eötvös József Gyakorló Általános Iskola és Gimnáziummal közösen indult 2016-ban egy közös, francia nyelvű program. Az óvodások hetente két alkalommal vesznek részt játékos francia nyelvü tevékenységeken. A vizsgálatunk arra is kiterjedt, hogy feltérképezzem, hogy milyen alternatívák vannak Nyíregyházán óvodáskori nyelvtanulásra. Sorra vettük a városban üzleti vállalkozásként müködő nyelviskolákat, így a Helen Doron Early English nyíregyházi nyelvoktató központját, a BubblEnglisht, a Little School Nyelviskolát és a Kicsik Vidám Háza családi bölcsődét, ahol kétnyelvü neveléssel segítik a gyermekek fejlődését. A kutatás eredményei igazolják, hogy 2017-ben a Nyíregyházán müködő óvodák többségében, a szülök növekvő érdeklődésével összhangban, felismerték a korai nyelvtanulás fontosságát, ezért egyre több intézmény szervez idegen nyelvi foglalkozásokat. Az ott dolgozó óvodapedagógusok és nyelvtanárok igyekeznek minél változatosabb módszerekkel biztosítani a 3-7 éves korú gyerekek idegen nyelvi fejlesztését. A korai nyelvtanulás elsődleges célja a pozitív attitüd és a motiváció felébresztése és megőrzése, hiszen ezekkel alapozható meg a későbbi sikeres nyelvtanulás. A gyermek számára nem okoz szorongást az idegen nyelven való megszólalás a korai idegennyelv-tanulás keretei között, mivel a keretek, a követelmények illeszkednek a korához és kommunikációs képességeihez. Gyermekkorban alakul ki a nyelvtanulás iránti érzékenység és a nyelvi fogékonyság is. A nyelvtanulás egész életen át tartó folyamat, ami kezdődhet bölcsődében vagy az óvodában, de még az középiskola vagy az egyetem befejezése után is tart. A korai nyelvtanításnak jelentős szerepe van a későbbi idegennyelv-tanulás folyamatának optimalizálásában, a különböző hatékony tanulási stratégiák kialakításában is. A stressz nélküli, élményalapú tanulás átvivődik a későbbi tudatos nyelvtanulásra is, ami a korai nyelvtanulás egyik legfőbb előnye.

\section{IRODALOM}

Bán Annamária (2013) Nevelj kétnyelvü gyereket! h.n.

Helen Doron (2010) A nyelv zenéje. Helen Doron Early English Országos Franchise Központ, Budapest. J.G.K. Kft.

http://helendoron.hu/kids-2-6 Hozzáférés: 2017-03-04 13:15

http://kivihaz.hu Hozzáférés: 2017-03-04 13:22

http://www.littleschoolgyereknyelviskola.hu Hozzáférés: 2017-03-03 16:42

Kasza Sándor, Bacsa Tibor, Bunovácz Dezső (1998): Szabolcs-Szatmár-Bereg megye kézikönyve. CEBA Kiadó 
Muszka Gabriella (2013): Az óvodás gyermek és az óvodai angoloktatás Debrecenben. Hajdúböszörmény. (szakdolgozat, kézirat)

Nemes Magdolna (2016): A többnyelvü családok nyelvhasználat lehetőségei In: Vargáné Nagy Anikó (szerk.) Családi nevelés. Debrecen. 115-132.

Nemes Magdolna, Hirzics Dóra (2016): A mesepedagógia alkalmazási lehetőségei a korai idegen nyelvi fejlesztésben. In: Renata Jukic, Katarina Bogatic, Senka Gazibara, Sara Pejakovic, Sanja Simel, Anikó Nagy Varga International Scientific Conference 'Global and Local Perspectives of Pedagogy'. Conference Proceedings Book (professional papers).Osijek, pp. 70-80.

Nemes Magdolna, Megyesiné Varga Zsuzsa (2016) A játék szerepe az idegen nyelvi foglalkozásokon. In: Vargáné Nagy Anikó, Pálfi Sándor (szerk.): Játékkal a világ körül_Play Around the World. Debrecen, Debreceni Egyetemi Kiadó.115-129.

Nemes Magdolna,Révészné Nagy Orsolya (2017): A mesterséges kétnyelvüségről - angolul nevelő magyar családok. In Éva Borsos, Zsolt Námesztovszki, Ferenc Németh (Szerk). A Magyar Tannyelvü Tanitóképzö Kar 2017-es tudományos konferenciáinak tanulmánygyüjteménye. Szabadka. 997-1010.

http://magister.uns.ac.rs/files/kiadvanyok/konf2017/kotet/ConfSubotica2017.pdf

Nikolov Marianne (2004): Az életkor szerepe a nyelvtanulásban..Modern nyelvoktatás. X. évfolyam 1. szám.

Téglás Zsolt (2017): A nyelvtanulás jelentösége: http://nyelvicentrum.com/node/1677 Hozzáférés 2017-03-31 20:53

Vargáné Nagy Anikó (2010): Az Oral history források jelentősége. In: Juhász Erika (szerk) Harmadfokú képzés, felnöttképzés és regionalizmus. Debrecen CHERD Hungary. 292298

Vargáné Nagy Anikó (2010): Az Oral history kutatási módszer bemutatása. In Kovácsné Bakosi Éva (szerk): Társadalomtudományi Tanulmányok III. Tanulmánykötet a kar oktatóinak írásaiból. Hajdúböszörmény. 31-46

\section{MELLÉKLET}

Az interjúalanyok

\begin{tabular}{|c|c|c|c|}
\hline Az interjúalany neve & Az interjú időpontja & Életkor & Intézmény típusa \\
\hline 1. H.P. & 2016.12 .16$. & 66 év & Óvoda \\
\hline 2. É.G. & 2017.01 .25$. & 59 év & Óvoda \\
\hline 3. B-B.A. & 2017.02 .10$. & 36 év & Óvoda \\
\hline 4. K.H. & 2017.02 .14$. & 34 & Óraadó \\
\hline 5. E.H. & 2017.02 .27$. & 40 & Óvoda \\
\hline 6. H.F. & 2017.01 .27$. & 26 & Nyelviskola \\
\hline 7. K.V. & 2017.02 .07$. & 42 & Óraadó \\
\hline 8. N.I. & 2017.02 .17$. & 59 & Általános Iskola \\
\hline
\end{tabular}




\section{INTERJÚ KÉRDÉSEK}

Bemutatkozás: Hogy hívják? Mi a foglalkozása? Milyen képzettséggel/ iskolai végzettséggel rendelkezik?

1. Hány éve dolgozik óvodás korú gyerekekkel?

2. Mikor kezdett korai idegen nyelvi foglalkozásokat tartani? Milyen indíttatásból?

3. Mikor kezdték el az idegen nyelvi foglalkozásokat? Milyen helyszínen, hol tartják a foglalkozásokat?

4. Hány fös csoportok vannak?

5. Milyen korosztályú gyerekekkel foglalkoznak? Hány éves kortól járhatnak önökhöz gyerekek?

6. Milyen gyakran tartják a foglalkozásokat? Korosztály szerint bontott csoportokkal dolgoznak?

7. Kik tartják a foglalkozásokat? Milyen szempontok szerint választották a nyelvtanárokat?

8. Milyen módszertani alapelveket vesznek figyelembe az óvodai idegen nyelvi foglalkozásokon?

9. Milyen tervezet alapján dolgoznak? (ütemterv, éves terv, stb.)

10. Milyen szempontok alapján választják ki a tevékenységek anyagát? Használják-e a klasszikus évszakokhoz igazított tevékenységszervezést?

11. Milyen eszközöket illetve szemléltetőeszközöket használnak? Bábok, Képek, fotók? Társas játékok? Fejdíszek?

12. Használnak-e auditív eszközöket?

13. A hanganyagokat honnan szerzik be?

14. Használnak-e audiovizuális eszközöket?

15. A játékosság, a mozgás és a különböző módszertanok (vizuális nevelés, külső világ megismerése, ének, zene, irodalmi nevelés) hogyan jelennek meg a foglalkozásokon? Olvasnak-e idegen nyelven meséket?

16. Milyen munkaformákat részesítenek előnyben?

17. Milyen módon tudják a leghatékonyabban a gyerekek szókincsét gyarapítani?

18. Próbálják-e megismertetni a gyerekekkel a célnyelvi országok kultúráját? (például angol nyelvhez zászló, emeletes busz stb.)

19. Milyen motivációs eszközöket alkalmaznak a gyerekek érdeklődésének felkeltésére és fenntartására?

20. Hány perces egy foglalkozás? Az időkeret korosztályonként változik-e?

21. Milyen szülői elvárások vannak? 